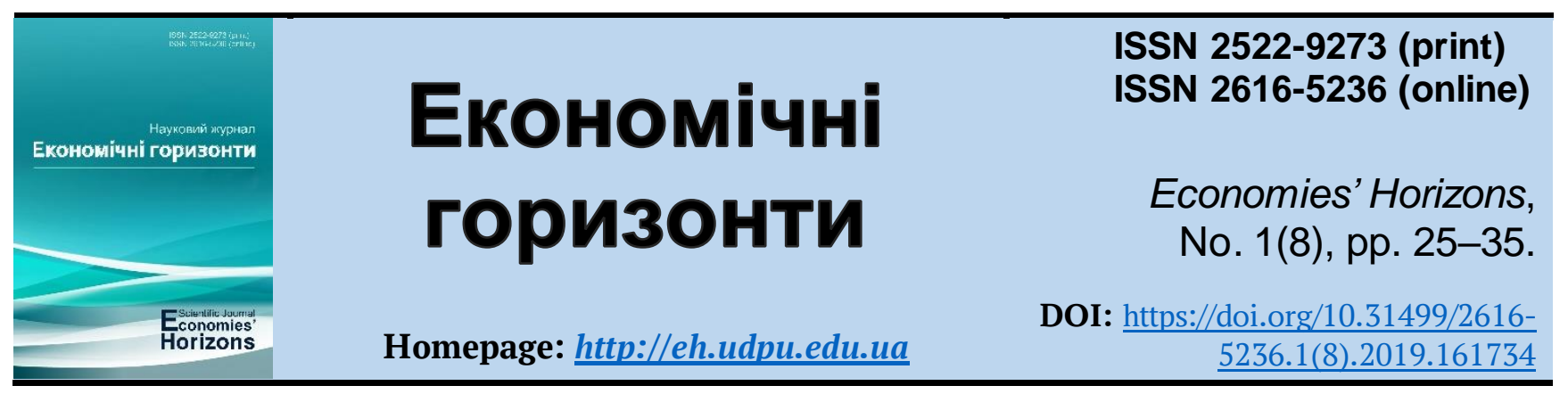

UDC 351/344:332.72(477)

\title{
Theoretical principles of the state land market regulation in Ukraine
}

\author{
Viacheslav V. Melnyk ${ }^{1}$, Cand. Ec. Sc., Associate Professor \\ Hanna M. Chyrva ${ }^{2}$, Cand. Ped. Sc., Associate Professor \\ Oleh M. Polishchuk ${ }^{3}$, Cand. Ec. Sc.
}

Received: 15 February 2019

Accepted: 20 March 2019

\begin{abstract}
Melnyk, V. V., Chyrva, H. M. and Polishchuk, O. M. (2019), "Theoretical principles of the state land market regulation in Ukraine”, Economies' Horizons, no. 1(8), pp. 25-35, doi: https://doi.org/10.31499/2616-5236.1(8).2019.161734.
\end{abstract}

Abstract. The agricultural land reformation is only the beginning of a large-scale and complex work on the settlement of land relations. The purpose of the research. There are described the theoretical positions and principles of the land market introduction in Ukraine, its regulation and creation of the corresponding legally-regulative framework in modern economic conditions. Methodology. The theoretical and methodological basis of the research is the dialectic method of reality's knowledge, a systematic approach to the socio-economic phenomena's study, theoretical researches of Ukrainian and foreign scientists on the issues of formation and functioning of the land market, legislative and other regulatory documents on the development issues in market conditions. The research methodology includes the system of generally scientific and special methods of the economic phenomena and processes' study. Results. The urgent need to complete the creation of infrastructure conditions, legislative and regulatory reform, which will promote the creation of a more efficient owner and ensure further intensive development of the Ukrainian agrarian sector, is substantiated. It is noted that functioning of the agricultural land market is an important step for further socio-economic development of Ukraine, including rural areas, on the basis of ecological principles, which will be the subject of further scientific research. It has been determined that land resources are the most valuable component of Ukrainian national wealth and one of the main factors of the economic development of our country, which would enable Ukraine to take an active part in solving world food problems and thereby provide a worthy place in the world. Practical meaning. It is noted that in the current Ukrainian realities the normative-legal base in the field of state management of land resources is characterized by imperfection in approaches and principles regarding the main provisions, as well as the presence of contradictions in the existing legislation. It was established that the reform of the land market should promote the efficient use of land resources and promote their rational use. This requires the participation of the state in regulating the use of land

\footnotetext{
${ }^{1}$ Pavlo Tychyna Uman State Pedagogical University; Associate Professor at the Department of Economy and Socio-behavioral Sciences; ORCID ID: https://orcid.org/0000-0001-9223-8646; e-mail: 73vmelnik@gmail.com.

${ }^{2}$ Pavlo Tychyna Uman State Pedagogical University; Associate Professor at the Department of Economy and Socio-behavioral Sciences; ORCID ID: https://orcid.org/0000-0003-3791-6111; e-mail: ch56@i.ua.

3 Uman National University of Horticulture; Senior Lecturer at the Department of Accounting and Taxation; ORCID ID: https://orcid.org/0000-0002-9859-9001; e-mail: olepol@ukr.net.
} 
resources, not only at the organizational and legal level, but also as an active land owner, which stimulates market processes. Prospects for further research. It is determined that for the effective functioning of the land market it is necessary to provide formal and material guarantees of ownership and circ ulation, the stability of the state and local policies regarding land real estate, investors, the formation of an effective system of spatial planning, etc.

Keywords: land market, agricultural land, reform, land parcels, land turnover, moratorium, price of land, land plots' lease.

JEL Classification: H 73, L 51, O 18, Q 15, R 52

Number of references: 45; number of tables: 0; number of figures: $\mathbf{0}$; number of formulas: $\mathbf{0}$.

\section{Теоретичні засади державного регулювання ринку землі в Україні}

Стаття надійшла: 15.02 .2019 Стаття прийнята: 20.03.2019
Мельник В. В. ${ }^{1}$, к. е. н., доцент

Чирва Г. М. ${ }^{2}$, к. пед. н., доцент

Поліщук О. М. ${ }^{3}$, к. е. н.
Melnyk V. V., Chyrva H. M., Polishchuk O. M. Theoretical principles of the state land market regulation in Ukraine. Економічні горизонти. 2019. № 1(8). C. 25-35. DOI: 10.31499/2616-5236.1(8).2019.161734.

Анотація. Реформування земель сільськогосподарського призначення $є$ тільки початком масштабної та складної роботи з урегулювання земельних відносин. Мета дослідження. Мета статті полягає в аналізі теоретичних положень та правових засад запровадження ринку землі в Україні, його регулювання і створення відповідної нормативно-правової бази в сучасних умовах господарювання. Методологія. У дослідженні застосовуються загальнонаукові теоретичні методи: узагальнення, пояснення, групування - для аналізу поглядів економістів на об'єкт дослідження та формулювання висновків контент-аналізу первинних джерел, аналіз і синтез для з'ясування основних наукових категорій дослідження, обгрунтування нових концептуальних положень, принципів, концепцій та категорій. Результати. Обгрунтовано термінову необхідність завершити створення інфраструктурних умов та законодавчо-нормативне реформування, що сприятиме створенню більш ефективного власника і забезпечить подальший інтенсивний розвиток аграрного сектора України. Відзначено, що функціонування ринку земель сільськогосподарського призначення $\epsilon$ важливим кроком для подальшого соціальноекономічного розвитку України, у тому числі сільських територій, на екологічних засадах, що буде предметом подальших наукових досліджень. Відзначено, що в сучасн их українських реаліях нормативно-правова база у сфері державного управління земельними ресурсами характеризується недосконалістю у підходах і принципах щодо основних положень, а також наявністю протиріч в діючому законодавстві. Практичне значення. Встановлено, що реформування ринку землі повинно сприяти ефективному використанню земельних ресурсів $\mathrm{i}$

\footnotetext{
1 Уманський державний педагогічний університет імені Павла Тичини; доцент кафедри економіки та соціально-поведінкових наук; ідентифікатор ORCID: https://orcid.org/0000-0001-9223-8646; e-mail: 73vmelnik@gmail.com.

2 Уманський державний педагогічний університет імені Павла Тичини; доцент кафедри економіки та соціально-поведінкових наук; ідентифікатор ORCID: https://orcid.org/0000-0003-3791-6111; e-mail: ch56@i.ua.

3 Уманський національний університет садівництва; старший викладач кафедри обліку і оподаткування; ідентифікатор ORCID: https://orcid.org/0000-0002-9859-9001; e-mail: olepol@ukr.net.
} 
сприяти їх раціональному використанню. Для цього необхідна участь держави в регулюванні використання земельних ресурсів, причому не тільки на організаційно-правовому рівні, але й як активного земельного власника, що стимулює ринкові процеси. Перспективи подальших досліджень. Визначено що для ефективного функціонування ринку земель необхідно забезпечити формальні та матеріальні гарантії власності й обігу, стабільність державної та місцевої політики відносно земельної нерухомості, інвесторів, формування ефективної системи просторового планування тощо.

Ключові слова: ринок землі, сільськогосподарські землі, реформа, земельні паї, обіг земель, мораторій, ціна землі, оренда земельних ділянок.

Кількість джерел: 45; кількість таблиць: 0; кількість рисунків: 0; кількість формул: 0.

\section{Introduction.}

The human society development at all times was inseparably linked with land, which remains the basis of providing the world population with food and a source of social wealth today. Since the onset of private land ownership, it has become a commodity that has led to the development of the land market. Restoration of private land ownership in Ukraine (since 1992) has become the basis for concluding the civil-law agreements concerning land plots and the launch of the land market. Land is a unique commodity, because its price increases over time (Sukhomlyn, 2011, p. 100).

Nowadays, there is no clear definition about the optimal model of land use, further development and land funds' state regulation in Ukraine.

Land is not a product of labor, it is formed and exists without any interference from the human (Official site of the Ministry of Agrarian Policy and Food of Ukraine, 2019).

"Land relations" in the Land Code of Ukraine (Article 2) - are the social relations regarding possession, use and disposal of land". In view of this, the task of land relations' regulation is one of the most important tasks of economic reforms in Ukraine. The success of socio-economic transformations, as well as the stability and security of the country depends on the policy of land relations (The Verkhovna Rada of Ukraine, 2011).

Land market reformation should encourage the efficient usage of land resources and promote their rational use. This requires the participation of the government in regulating the usage of land resources, not only at the organizational and legal level, but also as an active land owner, which stimulates market processes and is a participant. Land transformation should be carried out in a civilized way on the basis of a reliable scientifically substantiated and practically tested economic and legal mechanism (Hnatkovych, 2015, p. 52).

\section{Literature review.}

Numerous formation, development and regulation aspects of the land market in Ukraine are studied by both foreign and domestic scientists. In particular, among them there are A. H. Martyn (2011), D. S. Dobriak (2012), Y. Dorosh and O. Dorosh (2012), A. M. Tretyak (2013), I. Yu. Salman, A. S. Danilenko and O. A. Shust (2016), O. Kotykova and O. Albeshchenko (2017), A. Ya. Sokhnych, M. V. Smoliarchuk and O. A. Sokhnych (2018), M. A. Khvesyk and M. V. Ilina (2018), O. H. Chyrva and N. Yu Kohan (2018) and others.

At the same time, a large number of issues related to the functioning of the land market in Ukraine remains unsolved, controversial, and therefore need further resolution and improvement.

\section{Methods.}

While researching, the land resources departments' materials, the literary sources on the issue of research and the author's own observations results were used. The theoretical 
and methodological basis of the research is the dialectic method of reality's knowledge, a systematic approach to the socio-economic phenomena's study, theoretical researches of Ukrainian and foreign scientists on the issues of formation and functioning of the land market, legislative and other regulatory documents on the development issues in market conditions.

The research methodology includes the system of generally scientific and special methods of the economic phenomena and processes' study. They are based on a dialectical method of reality's acquaintance in the agrarian sector of Ukraine's economy in the development, interconnection and interaction. Methods of analysis and synthesis are used to study the essence and features of institutional factors of the land relations' transformation; the unity of logical and historical approaches, quantitative and qualitative while characterizing the formation and development of the agricultural lands' market in Ukraine; structurally-functional method in studying the structure and functions of the reformed land ownership and use institutions; the systematic approach is used in identifying and disclosing the main contradictions that arise in the process of social development.

\section{Research objectives.}

Research goals' formation is related to the definition of the theoretical fundamentals of the land market introduction in Ukraine, its regulation and the creation of an appropriate normative and legal regulatory framework in the modern market economy.

\section{Results and discussions.}

S. Vasyliev emphasized that in agriculture the critical role belongs to the land. Of the 60.4 million hectares of land in Ukraine, 41.8 million hectares $(69.3 \%)$ are agricultural land. By this indicator, our country ranks first in $\mathrm{Eu}-$ rope and is among the first twelve in the world (Vasyliev, 2010, p. 152). I. Mosiiuk noted that the land resources of our country by $60 \%$ consist of the most valuable in the world of humus, and their share in world reserves is, according to various estimates, from 8 to 15\% (Mosiiuk,
2011, p. 158). The country has unique opportunities to win leading positions in the world food markets thanks to the supply of environmentally friendly products, since it owns about 8 million hectares of relatively clean lands (Sukhomlyn, 2011, p. 46).

The experts have estimated that if Ukraine rationally operates its potential, it will be able to feed up to $140-180$ million people a year (The Verkhovna Rada of Ukraine, 2017). Taking into consideration the aforementioned facts, N. Tkachenko confidently declares that land resources are the most valuable component of the Ukraine's national wealth and one of the economic development and prosperity main factors of our country. Thanks to its capabilities, Ukraine could take an active part in world food problems' solving and possess a worthy place in the world stage. But it does not use its advantages, moreover, it buys huge batches of low-quality products, which are basically composed of artificial fillers that have a detrimental effect on the human body and gradually transforms into an import-dependent country. With the world's most fertile soils, the country imports Polish pork, Egyptian potatoes, Chinese buckwheat, sugar cane (Tkachenko, 2010, p. 159).

Therefore, as noted by Yu. Semeriak, land resource's governmental regulation potential issues, the provision of an appropriate land resources management process, strengthening the control over their rational use are of crucial importance (Semeriak, 2011, p. 73).

S. Tymchenko confirms the governmental private land ownership restrictions in the countries of Eastern Europe. In Bulgaria, the family may own not more than 30 hectares, and in areas of intensive agriculture no more than 20 hectares. Here there is a 10 -year moratorium on the land plots' purchase, acquired in the ownership of the state and collective land fund (Tymchenko, 2013, p. 3).

In particular, A. Tretiak points out that, as a result of negotiations with the EU and the acceptance of agreements, Hungary and the Czech Republic have agreed that from the moment of joining the EU only 7 years later, 
foreign citizens and companies from the $\mathrm{EU}$ countries will be able to buy their agricultural and forest lands. At the same time, farmers from EU countries can buy land in Hungary in three years, subject to a preliminary lease in this period. From the moment of joining the EU, Poland has a 12-year moratorium on the purchase by foreign companies of land in the country (Tretiak, 2003, p. 63).

O. Shkilov emphasizes that renting as a form of land market operations should facilitate the movement of land to a caring owner. This corresponds to the modern requirements for the optimal size economic structures' formation in the agrarian sector. However, this does not fully happen to Ukraine. Lease agreements are concluded mainly for short periods (up to 5 years), their share in 2006 amounted to $81.6 \%$ (Shkilov, 2008, p. 137).

M. Fedorov points out that the consequence of the ineffective institutional relations between land owners and renters is the inappropriate use of this asset. This is caused by existing institutions that encourage the tenant to irresponsibility, and it forms among peasants a persistent stereotype of indifferent attitude towards his property as a source of income. The reason is the lack of an effective trust institute, the peasant's rights protection, and, most importantly, the sense of the business' temporality, which is mainly based and operates not on own, but on borrowed assets of land and property. According to scientists, this is the main institutional paradox, which holds back the establishment of an effective, competitive agrarian business - economically responsible for society and the country (Fedorov, 2003, p. 26).

Today M. Bohira notes that a considerable part of the arable land is not cultivated, and the rest is cultivated with the violation of the elementary farming rules (Bohira, 2012, p. 17). The main reason for this is the lack of a proper legal and material-technical base for the landowners (owners of land plots (shares) and land users). Therefore, the strategy of land relations' market transformation in Ukraine should provide the establishment of the more effective land management forms, first of all agricultural production. At the moment, O. Hnatkovych says that objective and subjective factors determine the orientation and dynamics of modern changes in strategic land use rationalization's imperatives in the future, also. In particular, it refers to the status of land and land relations (Hnatkovych, 2015, p. 32). Ukraine is close to the opening of the agricultural land market, as H. Cherevko believes. Therefore, it is necessary to reconcile the main "rules of the game" in this area, prevent abuses, find a balance between the interests of all players - from the shareholder to the large agrarian holding (Cherevko, 2012, p. 36).

Thus, as V. Yarovyi notes, the most important characteristics of the entrepreneurial environment in the agrarian sphere is the seasonality of production, use of land as a main asset, the dependence of the results on the natural environment and the factor of time. It is this sphere that requires the establishment of an effective institutional structure of land relations regulation in order to safeguard the interests of agricultural producers, consumers and the government (Yarovyi, 2006, p. 88).

A. Tretiak is supporting the aforementioned statement, points out to the practice of historical development of land market turnover, which confirms that market mechanisms are not self-sufficient and require organized intervention from both the market participants of the agricultural land and from the government side. For functioning of the land market it is necessary to provide formal and material guarantees of ownership and circulation, stability of state and local policies concerning land and other real estate and investors, and the formation of an effective system of spatial planning. This should be accompanied by perfect formal procedures for the market functioning, especially administrative and judicial procedures relating to the establishment and registration of land ownership (Tretiak, 2009, p. 24). As for Ukraine, the implementation of the land relations' reform is associated with the 
emergence of new social and socio-economic changes, in order to revive the landowner and create legislative responsibility mechanisms for the results.

In this context A. Shchapov notes that the state regulation of institutional problems of the land market formation should take into account such aspects as the creation of an affordable and complete monitoring system of the land market (information on real estate, sales prices, land auctions, data on rent of land plots and rent); the improvement of transaction costs in the field of land relations (simplification of the land transactions procedures, including review of notaries' fees, costs for land management works, fees and terms for obtaining legal documents, registration of transactions with real estate objects); creation of an appropriate land market infrastructure (land auctions, mortgage institutions, real estate companies) (Shchapov, 2008, p. 138).

M. Moskva states that on December 18, 1990 the Verkhovna Rada of Ukraine approved the Resolution "About the Land Reform” (Moskva, 2013, p. 139), its main task was land redistribution in order to create conditions for the equal development of various forms of management, rational use and protection of land, as well as the formation of a multioriented economy of Ukraine.

At the same time, new trends in the organization envisage further improvement of the normative-legal legislation. Such documents were the Resolution "On accelerating the land reforms and privatization of land" (The Verkhovna Rada of Ukraine, 1992) and Decree of the Cabinet of Ministers of Ukraine on December 26, 1992 "On privatization of land plots voice of Ukraine” (Cabinet of Ministers of Ukraine, 1992).

Two years later, the Decree of the President of Ukraine dated November 10, 1994 “On urgent measures of accelerating the land reform in the field of agricultural production" (President of Ukraine, 1994) accelerated the process of privatization of land.

A logical postponement in the context of settling issues of use and protection of land was the Decree of the President of Ukraine of August 8, 1995 "On the procedure for land allotment transferred to the collective property of agricultural enterprises and organizations" (President of Ukraine, 1995), as well as the approval of the Constitution of Ukraine on June 28, 1996.

L. Bulavka points out that as a result of transformations, large land plots were divided into a number of small pieces. The market economy and its relations require commodity producers to strictly follow to economies of scale, to carefully spend on material resources, to introduce resource conservation measures, new technologies in order to reduce their own production costs and improve product quality, since this is the only opportunity to maximize profits (Bulavka, 2013, p. 138).

The aforementioned land reform measures were not fully prepared and supported financially. Therefore, for ensuring the effective use of the powerful land resources of Ukraine in 2001, it was developed and approved by the Decree of the President of Ukraine dated May 30, 2001 "Main directions of land reform in Ukraine for 2001-2005" (President of Ukraine, 2001). This Decree provided for a system of measures related to the creation of mechanisms for state regulation and ways to accelerate land reform in Ukraine.

Significantly contributed to the prolongation of the land reform was the Land Code of Ukraine approved on October 25, 2001, which took into account the norms of the Constitution of Ukraine. According to the Land Code of Ukraine, land is the main national wealth that is under special governmental protection (The Verkhovna Rada of Ukraine, 2001).

Thus, the land ownership, which is the main tool in agricultural production, is acquired by economic entities only in accordance with the current legislation. Article 22 of this Code determines that agricultural lands are the lands provided for agricultural production, agricultural research and education activities, placement of appropriate industrial infrastructure, including wholesale markets for 
agricultural products or intended for these purposes. The specified legal act defines the order of this category land distribution among different economic entities. Characterizing the legal basis for land use, The Code establishes the rights and obligations of land owners. Such rights are: to sell or otherwise to alienate a land plot, transfer it to a lease, a pledge, a legacy; self-management on land; ownership of crops and planting of agricultural and other crops, on the produced products; to use in established way for private needs the existing mineral resources, turf, forest plantations, water objects, as well as other useful properties of the land available; for damages, in cases specified by law; to build residential buildings, industrial and other buildings and structures. Owners of land plots are obliged: to ensure the usage by their intended purpose; to fulfil the environmental protection legislation requirements; to pay the land tax in time; not to violate the rights of neighboring land plots owners and land owners; to increase soil fertility and to preserve other beneficial properties of the soil; provide executive authorities and local governments in due time with relevant information on the situation and use of lands and other natural resources in accordance with the procedure established by law; adhere to the rules of good neighborliness and restrictions related to the installation of land easements and security zones; keep geodetic signs, anti-erosion structures, networks of irrigation and drainage systems; at its own expense, bring the land plot in its previous condition in case of illegal alteration of its relief, except for the implementation of such a change by the owner of the land, when the bringing to the previous condition is carried out at the expense of the person who illegally changed the relief (The Verkhovna Rada of Ukraine, 2001).

In addition to the abovementioned, for the purpose of detailing, other normative-legal acts were approved, in particular the Law of Ukraine "On Land Management" dated May 22,2003 , which defined the legal and organizational fundamentals of land management activities and aimed to regulate the relations that arise between municipal authorities, local self-government bodies, legal units and individuals for the sustainable development of land use (The Verkhovna Rada of Ukraine, 2003a).

A little later, the Law of Ukraine "On the procedure for allocation in kind (on the ground) of land plots to owners of land shares (shares)" was implemented on June 5, 2003 (The Verkhovna Rada of Ukraine, 2003b) and the Law of Ukraine "On Land Protection" on June 19, 2003, which defined the legal, economic and social bases of land protection in order to ensure their rational use, reproduction and increase of soil fertility, other soil useful properties, preservation of soil ecological functions and protection of the environment (The Verkhovna Rada of Ukraine, 2003c).

It is worth to say that the Decree of the Cabinet of Ministers of Ukraine dated October 26, 2011 No. 1072-p "On approval of the action plan for land reform and the creation of a transparent market for agricultural land", which outlines the main directions of the land reform in Ukraine for 2011-2020. This plan foresees the development and submission to the Cabinet of Ministers of Ukraine of draft laws: on simplifying the procedure for establishing settlements' boundaries, on approval of the land relations' National Development Program in Ukraine to 2020, on variations to some legislative acts of Ukraine concerning the abolition of free land privatization, organizing, and bringing to a common electronic format inventory information; draft resolutions on the approval of documents, regulating the issue of the State Land Cadaster, the approval of the Concept of the Land's Use and Protection National Program, etc. (Cabinet of Ministers of Ukraine, 2011).

At the same time, the Verkhovna Rada of Ukraine accepted the Law of Ukraine "On the State Land Cadastre" on July 7, 2011, which fully entered into force from January 1, 2013 (The Verkhovna Rada of Ukraine, 2011). Implementation of this Law is one of the 
conditions for stopping the moratorium and the introduction of agricultural land market for agricultural commodity production, as well as restoration of the possibility to enter land shares into main capital of economic partnerships. However, this, unfortunately, has not accelerated the formation of the land market.

However, on December 27, 2011, the Verkhovna Rada continues the moratorium on the sale of agricultural land by 1 January 2013, and on November 20, 2012, the Verkhovna Rada of Ukraine approves the Law No. 11315, which prolongs the moratorium on the sale of agricultural land until January 1, 2016. The document contains a rule according to which, by January 1, 2016, is not allowed: to purchase and sale an agricultural land plots of governmental and communal property, except for their extraction (redemption) for public needs; to purchase or sale or other means of alienation of land plots and change of the intended use if owned by citizens and legal entities for conducting commodity agricultural production, altogether land plots allocated in kind (on the ground) to owners of land shares for the management of a personal farm, as well as land shares, in addition to their inheritance, the exchange of land to another land plot in accordance with the law and seizure (redemption) of land for public needs (The Verkhovna Rada of Ukraine, 2012).

In 2016, the Verkhovna Rada adopts a law project that provides the extension of moratorium of the agricultural land sales until January 1,2018 . "This market should be transparent and fair, competitive and efficient, it would make it impossible to deal with any shady land deals. That is why it is necessary to extend the moratorium on the agricultural land sale to the proper legislative provision for the introduction and regulation of land use, but not before January 1, 2018", the explanatory note to the bill says (The Verkhovna Rada of Ukraine, 2016).

The Parliament in 2018 failed to adopt the relevant legislation on the agricultural land circulation, therefore, the moratorium was renewed again until the necessary procedures were settled, but no earlier than 01.01.2019. Thus, the problem of the land market remains unclear at the theoretical level, and it is inconsistent at the legislative level and as a result is quite controversial in practice (The Verkhovna Rada of Ukraine, 2018).

A. Tretiak confirms that a significant part of the peasants who received the right to a land part (share) are retirees who can not handle it on their own, but they can not exercise their ownership right through the moratorium. Without the right of free choice, the peasants began to lease their land by major agribusiness for a symbolic fee, which in addition violate the crop rotation, remove perennial and annual grasses and replace them with rape and another similar crops, that break the balance of nutrients, water and air, and there is no restoration works, practically. Today in Ukraine there are about 60 agrarian holdings, under the control of which there are more than $24 \%$ of arable land (Tretiak, 2013, p. 27).

In other words, I. Kyrylenko says that farming on rented plots in the way used by Ukrainian agrarian holdings will lead to the complete exhaustion of the most productive lands. According to soil surveys, $80 \%$ of Ukrainian agricultural land has been eroded and lost its fertility (Kyrylenko, 2009, p. 45).

Therefore, as says M. Fedorov, strategic vision of land reform in modern conditions of state-creation should be based on the principles based on solving the social, economic and environmental problems of highly efficient and ecologically safe land use, intensification fertility and comprehensive soil protection, cross-sectorial type of land reform relations and a systematic approach to solve the socioeconomic and environmental principles of land reform, forming civilized and regulated by the government land reform market, as well.

It is the place where authorities should play an important role and they must balance the positive and negative aspects of land privatization, to carry its legal training, to work out flexible land market regulation mechanisms, to evaluate the possibility of a 
local point land privatization (Fedorov, 2004, p. 7).

To organize the process of sale, lease, mortgage, inheritance and gift of land, in present conditions according to V. Halushko, Yu. Bilyk and A. Danylenko is needed:

- the appropriate institutional infrastructure (the land law system, the State Land Cadastre system and registration of land rights, land estimates, professional experts);

- availability of credit resources and free access to them;

- taxation system based on natural-resource potential (Halushko, Bilyk (ed.) and Danylenko (ed), 2006).

\section{Conclusions.}

Thus, the formation of the land market in Ukraine today requires the approval of well weighted and grounded decisions. At the same time, it is necessary to take into consideration the ongoing discussions that are related to the feasibility of further prolonging the moratorium or the need for its abolition. As a result, there are such negative phenomena as the purchase and concentration of large agricultural land areas by financial and industrial groups, uncontrolled influence on the intended agricultural land use, "speculation" on land plots and the alienation of land at a significantly lower price than that is economically justified etc.

Thus, the reformation of land relations in Ukraine has not achieved the goal and as a consequence, there is a need for a further modernization process, while the civilized land market creation issue still remains open.

\section{References}

Bohira, M. O. (2012), "Problems in land usage, caused by land reform in Ukraine, and ways to overcome them", Land management herald, no. 3, pp. 16-18.

Bulavka, L. V. (2013), "Functioning of private subsidiary households in conditions of market transformation", available at: http://intkonf.org/bulavka-lv-funktsionuvannya-osobistih-pidsobnih-gospodarstv-naselennyav-umovah-rinkovoyi-transformatsiyi// (Accessed 10 February 2019).

Cabinet of Ministers of Ukraine (1992), Decree of the Cabinet of Ministers of Ukraine "On privatization of land plots voice of Ukraine”, available at: https://zakon.rada.gov.ua/laws/card/en/15-92 (Accessed 10 February 2019).

Cabinet of Ministers of Ukraine (2011), Resolution of the Cabinet of Ministers of Ukraine "On approval of the action plan for land reform and the creation of a transparent market for agricultural land", available at: https://zakon.rada.gov.ua/laws/show/1072-2011-\%D1\%80?lang=en (Accessed 10 February 2019).

Cherevko, H. (2012), "Agricultural holdings as new organizational forms of a large-scale farm in the agribusiness of Ukraine”, Agrarian Economics, no. 1-2, vol. 5 pp. 32-39.

Chyrva, O. H. and Kohan, N. Yu. (2018), "Features of state regulation of land relations in foreign countries", Economies' Horizons, no. 4(7), pp. 28-36, doi: https://doi.org/10.31499/2616-5236.4(7).2018.161718.

Dobriak, D. S. (2012), "Problems of modern land management", Land management herald, no. 1, pp. 30-34.

Dorosh, Y. and Dorosh, O. (2012), "Ecological-economic imperatives of land reform in market conditions”, Land management herald, no. 3-4, pp. 30-33.

Fedorov, M. M. (2003), "Organizational and economic fundamentals for the formation of the agricultural lands market”, Economy of Agro Industrial Complex, no. 1, pp. 25-31.

Fedorov, M. M. (2004), "Objective necessity and basic methodical principles of improvement of the economic land valuation method", Economy of Agro Industrial Complex, no. 5, pp. 3-11.

Halushko, V. P., Bilyk, Yu. D. (ed.), Danylenko, A. S. (ed.) et al. (2006), Formation of the land market in Ukraine, "Urozhai", Kyiv, Ukraine, 280 p.

Hnatkovych, O. D. (2015), "State policy in the field of economic land relations' regulation", Public Administration: Improvement and Development, no. 4, available at: http: www.dy.nayka.com.ua/?op=1\&z=835 (Accessed 10 February 2019).

Khvesyk, M. A. and Ilina, M. V. (2018), "Methodological principles of differentiation of rural areas”, Economy of Agro-Industrial Complex, no. 4, pp. 12-18. 
Kotykova, O. and Albeshchenko, O. (2017), “An indication of the sustainable development of Ukraine in global dimensions”, Baltic Journal of Economic Studies, vol. 3, no. 5, pp. 196-202, doi: http://dx.doi.org/10.30525/2256-0742/2017-3-5-196-202.

Kyrylenko, I. H. (2009), “Topical issues of the market of agricultural lands”, Economy of the Agro Industrial Complex, no. 3, pp. 44-46.

Martyn, A. H. (2011), Rehuliuvannia rynku zemel v Ukraini [Regulation of land market in Ukraine], National University of Life and Environmental Sciences of Ukraine, Kyiv, Ukraine, 252 p.

Mosiiuk, I. P. (2011), "Land resource potential of agrarian production and rational nature use of Ukraine", Scientific Reporter of NUBiP of Ukraine. Section: Economics, agrarian management, business, vol. 163, part 3, pp. 259-261.

Moskva, M. H. (2013), “Land reform - precondition for the Ukrainian village development”, Rozvytok silskykh terytorii Karpatskoho rehionu: stan ta perspektyvy [Development of rural territories of the Carpathian region: the situation and prospects], Materialy kruhloho stolu [Materials of round table], Lviv, Ukraine, pp. 158-162.

Official site of the Ministry of Agrarian Policy and Food of Ukraine (2019), "Materials for the project Agrarian Code of Ukraine”, available at: http://minagro.gov.ua/ (Accessed 10 February 2019).

President of Ukraine (1994), Decree of the President of Ukraine "On urgent measures of accelerating the land reform in the field of agricultural production", available at: https://zakon.rada.gov.ua/laws/show/666/94?lang=en (Accessed 10 February 2019).

President of Ukraine (1995), Decree of the President of Ukraine "On the procedure for land allotment transferred to the collective property of agricultural enterprises and organizations", available at: https://zakon.rada.gov.ua/laws/show/720/95?lang=en (Accessed 10 February 2019).

President of Ukraine (2001), Decree of the President of Ukraine "Main directions of land reform in Ukraine for 2001-2005”, available at: https://zakon.rada.gov.ua/laws/show/372/2001?lang=en (Accessed 10 February 2019).

Salman, I. Yu., Danilenko, A. S. and Shust, O. A. (2016), "Legal regulation of land relations in Ukraine", Ekonomika ta upravlinnia APK, no. 1/2, pp. 44-48.

Semeriak, Yu. A. (2011), "Land Fund of Ukraine and its use", Scientific Bulletin of NLTU of Ukraine, vol. 21.2, pp. $70-74$.

Shchapov, A. H. (2008), "The right to restitution: the theory and practice of land reform in foreign countries", Agrarian and Land Law, no. 1, pp. 136-142.

Shkilov, O. V. (2008), "Efficiency of leased land use and preservation of their fertility", Economy of Agro Industrial Complex, no. 6, pp. 7-11.

Sokhnych, A. Ya., Smoliarchuk, M. V. and Sokhnych, O. A. (2018), "Institutional transformations in the system of state management of land resources", International Journal of Innovative Technologies in Economy, no. 5(17), vol. 2, pp. 7-13, doi: https://doi.org/10.31435/rsglobal ijite/01062018/5665.

Sukhomlyn, I. O. (2011), Zemelni vidnosyny: osnovy rehuliuvannia: zbirnyk systematyzovanoho zakonodavstva [Land relations: basics of regulation: a collection of systematic legislation], Blitz-Inform, vol. 2, Kyiv, Ukraine, $192 \mathrm{p}$.

The Verkhovna Rada of Ukraine (1992), Resolution of the Verkhovna Rada of Ukraine "On accelerating the land reforms and privatization of land", available at: https://zakon.rada.gov.ua/laws/show/2200-12 (Accessed 10 February 2019).

The Verkhovna Rada of Ukraine (2001), The Law of Ukraine "The Land Code of Ukraine", available at: https://zakon.rada.gov.ua/laws/show/2768-14 (Accessed 10 February 2019).

The Verkhovna Rada of Ukraine (2003a), The Law of Ukraine "On Land Management", available at: https://zakon.rada.gov.ua/laws/show/858-15?lang=en (Accessed 10 February 2019).

The Verkhovna Rada of Ukraine (2003b), The Law of Ukraine "On the procedure for allocation in kind (on the ground) of land plots to owners of land shares (shares)", available at: https://zakon.rada.gov.ua/laws/show/899-15 (Accessed 10 February 2019).

The Verkhovna Rada of Ukraine (2003c), The Law of Ukraine "On Land Protection", available at: https://zakon.rada.gov.ua/laws/main/962-15?lang=en (Accessed 10 February 2019).

The Verkhovna Rada of Ukraine (2011), The Law of Ukraine "On the State Land Cadastre", available at: https://zakon.rada.gov.ua/laws/main/3613-17?lang=en (Accessed 10 February 2019). 
The Verkhovna Rada of Ukraine (2012), The Law of Ukraine "On Amendments to the Land Code of Ukraine", available at: https://zakon.rada.gov.ua/laws/show/5494-vi?lang=en (Accessed 10 February 2019).

The Verkhovna Rada of Ukraine (2016), Draft Law “On Amendments to Section X “Transitional Provisions" of the Land Code of Ukraine on the extension of the prohibition on the alienation of agricultural land", available at: http://w1.c1.rada.gov.ua/pls/zweb2/webproc4 1?pf3511=60199 (Accessed 10 February 2019).

The Verkhovna Rada of Ukraine (2017), Draft Law “On land market”, available at: http://w1.c1.rada.gov.ua/pls/zweb2/webproc4 1?pf3511=62540 (Accessed 10 February 2019).

The Verkhovna Rada of Ukraine (2018), The Law of Ukraine "On Amendments to Section X "Transitional Provisions" of the Land Code of Ukraine regarding the extension of the prohibition on the alienation of agricultural land", available at: https://zakon.rada.gov.ua/laws/show/2666-19?lang=en (Accessed 10 February 2019).

Tkachenko, N. M. (2010), “Topical issues of accounting for land plots in Ukraine under conditions of different forms of ownership", Economics Science Reporter, no. 2 (18), pp. 162-165.

Tretiak, A. M. (2003), "Ways of regulating the land market”, Bulletin of Agrarian Science, no. 10, pp. 62-66.

Tretiak, A. M. (2009), "Formation of a new management system for state-owned land", Land Management Bulletin, no. 1, pp. 20-25.

Tretiak, A. M. (2013), "Institutional environment of mortgage lending on agricultural land and land management in Ukraine”, Land Law, no. 8. pp. 23-30.

Tymchenko, S. P. (2013), "The final chord of the land reform will be the adoption of a law on the abolition of the moratorium", Scientific Bulletin of NLTU of Ukraine, vol. 21.2, pp. 2-3.

Vasyliev, S. V. (2010), "Land reform in Ukraine: results analysis and prospects”, Bulletin of the Dnipropetrovsk State Agrarian University, no. 1, pp. 152-155.

Yarovyi, V. D. (2006), "Priorities for the regulation of land relations in agriculture", Scientific Bulletin of the National Agricultural University, no. 97, pp. 87-89.

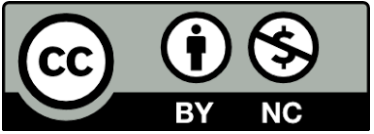

Цей твір ліцензовано на умовах Ліцензії Creative Commons «/з Зазначенням Авторства - Некомериійна 4.0 Міжнародна» (CC BY-NC 4.0).

This is an open access journal and all published articles are licensed under a Creative Commons "Attribution-NonCommercial 4.0 International" (CC BY-NC 4.0). 